MÓDSZEREK A TERÜLET- ÉS

TELEPÜLÉSFEJLESZTÉSBEN / METHODS IN REGIONAL

AND SETTLEMENT DEVELOPMENT

\title{
Vidékfejlesztési támogatások munkaerőpiaci hatásainak települési szintü útmodellezése magyarországi községek mintáin
}

\section{Labour market effects of rural development funds A path analysis approach}

\author{
HORZSA GERGELY
}

HORZSA Gergely: doktorjelölt, Budapesti Corvinus Egyetem, Szociológia Doktori Iskola; 1093 Budapest Fővám tér 8.; horzsagergely@gmail.com; https://orcid.org/00000003-2043-0633

KULCSSZAVAK: vidékfejlesztés; hatáselemzés; Új Magyarország Vidékfejlesztési Program; Európai Unió; útmodell

ABSZTRAKT: A tanulmány az Új Magyarország Vidékfejlesztési Program (ÚMVP) keretében felhasznált EU-s, szükebb értelemben vett (3. tengelyes) vidékfejlesztési támogatások munkaerőpiaci hatásaival foglalkozik. A vizsgálat azért fontos, mert a vidékfejlesztési programok hatáselemzése általában a projektek teljesítményeinek számbavételére korlátozódik, az érdemi hatáselemzés mind a hazai, mind a nemzetközi szakirodalomban ritka és nem megbízható. Az ÚMVP szűkebb értelemben vett vidékfejlesztési céljaiként a vállalkozásösztönzést, a munkahelyteremtést és a jövedelemnövelést nevezi meg a helyi gazdasági diverzifikáció keretében. Ennek megfelelően a tanulmány elemző része a harmadik tengelyes támogatások elköltésének jövedelemre gyakorolt közvetlen és közvetett hatásával foglalkozik, a magas mérési szintủ változók által lehetővé tett lineáris regressziószámításokon alapuló útmodellezéssel - a hazai községek három almintájában (agglomerációs, nem agglomerációs és leghátrányosabb helyzetü falvak). A modellek a munkaerőpiaci helyzetet mérő változóknak a 2006 és 2016 közötti, egy főre vetített változását magyarázzák az egy főre eső elköltött (harmadik tengelyes) támogatások függvényében. Az elemzés legfontosabb eredményei: 1. A vidékfejlesztési támogatások mind közvetlenül, mind a vállalkozások foglalkoztatottsági arányának növelésén keresztül közvetetten befolyásolták a helyi jövedelmi helyzetet a nem agglomerációs településeken. 2 . Az agglomerációs településeken a változók kevésbé

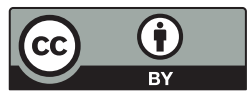


magyarázták a jövedelmek alakulását, mint másutt. 3. A leghátrányosabb térségekben a mikrovállalkozások arányának bővülése negatívan befolyásolta a foglalkoztatást, csökkentve a vidékfejlesztési támogatások összességének pozitív hatását.

Gergely HORZSA: doctoral candidate, Doctoral School of Sociology, Corvinus University of Budapest; Fővám tér 8., H-1093 Budapest; horzsagergely@gmail.com; https://orcid.org/0000-0003-2043-0633

KEYWORDS: rural development; policy impact assessment; Central Eastern Europe; European Union, path analysis

ABSTRACT: This paper examines the impact on the labour market of European Union EAFRD (European Agricultural Fund for Rural Development) funds spent on rural development in Hungarian villages over the 2007-2013 EU budget period. The relevance of the study results from the scarcity of development policy impact assessment in the social sciences, in particular with regard to EU funds in Central Eastern Europe. Most analyses are based exclusively on research into the macro- or micro-scale status of the socio-economic environment before and after policy interventions. However, there is some previous international and Hungarian research using experimental tools and complex indices to measure more accurately the real impact of such rural development policies. These, on the other hand, argue that the complexity of project objectives makes it incredibly difficult to properly assess the impact of such policies.

The former Hungarian rural development strategy titled "New Hungary Rural Development Programme 2007-2013" provides a unique opportunity to examine the impact of this policy on labour market outcomes. An objective of the programme is related to the "third axis funds" of rural development policy of the previous EU budget period, which can be considered as rural development in the narrower sense (i.e. excluding agriculture). The aim is to improve quality of life in rural areas by supporting micro-enterprises, creating new jobs and increasing incomes, in particular by diversifying the local economy. As some $€ 3$ billion of EAFRD funds were spent on rural development and Hungary was one of the countries with the highest share of these international funds in local development, expenditure at settlement level is very well documented so that a good research framework for the analysis of this issue exists.

For the analysis of interactions, linear regression-based path analyses were employed. As part of the research, a database was developed at the settlement level on expenditure for the third axis funds and labour market variables. The variables were calculated per capita and (in the case of labour market variables) a change in their values was introduced into the model (instead of their cross-sectional value) for the period 2006-2016. Three sub-samples were compiled: agglomeration villages ( $n=471)$; non-agglomeration villages $(n=2337) ;$ villages of the 33 least developed micro-regions $(n=644)$. The research results are as follows: 1 . The funds for rural development influenced the average income both by the increasing number of enterprises and by jobs in non-agglomeration villages. 2. In the agglomeration villages, external factors are much more important in explaining income than in other villages. 3. In contrast to other effects, enterprises in the least developed regions have a negative impact on the number of jobs and thus reduce the positive impact of the funds on income.

\section{Bevezető}

A tanulmány az Új Magyarország Vidékfejlesztési Program munkaerőpiaci hatásainak megragadására tesz kísérletet. Bár a magyarországi fejlesztések túlnyomó részét kitevő európai uniós finanszírozású programok eredményeit 
értékelik, ezek hatáselemzésére mindezidáig kevesen vállalkoztak. A tanulmány ezt a hiányosságot igyekszik pótolni a magyarországi községek alapsokaságán, illetve ezek három alcsoportjában végzett - egyszerű lineáris regressziókon alapuló - útmodellezéssel. Az elemzés során települési szinten azt vizsgálom, vajon van-e - a szakpolitikai elképzelések által feltételezett - lineáris összefüggés a (szúkebb értelemben vett) vidékfejlesztési támogatások mennyisége, illetve a foglalkoztatottak és a helyi vállalkozások száma, valamint az átlagjövedelmek változása között.

A redisztributív fejlesztési támogatások értékeléséhez be kell mutatnunk, hogy az elérni kívánt célok teljesültek-e, vagy legalábbis a vágyott célok felé elmozdulás következett-e be. Különösen igaz ez az európai uniós fejlesztési forrásokra, ahol részletes beszámolási kötelezettség terheli a kedvezményezetteket a bürokrácia több szintjén. A hatáselemzések minőségükben is, valamint a vizsgált outputok és a módszerek tekintetében is sokfélék, az eredmények puszta bemutatásától a komplex mutatókon alapuló makroelemzéseken keresztül az aprólékos, általában egyetlen projektre fókuszáló kvalitatív elemzésekig terjedhetnek.

Azon a kérdésen túl, hogy vajon az egyes programok az elvárt indikátorokat teljesítik-e (amivel kapcsolatban a legtöbbször aligha merül fel probléma, különösen azért, mert ezek definíció szerint kézzel fogható, közvetlen és rövid távú eredményt jelentenek, s mert minden fél ezek teljesítésében érdekelt), a megvalósított programok tényleges hatásainak mérése sokféle akadályba ütközik, amelyek közül számunkra a módszertani akadályok a legérdekesebbek. $\mathrm{E}$ körben a legfontosabbakat a hatáselemzéshez nélkülözhetetlen adekvát kontrollcsoportok hiánya, a társadalomtudományos kísérletek etikai kérdései jelentik (Baker 2000), továbbá az, hogy az elérni kívánt társadalmi-gazdasági célokat számtalan más külső hatás is befolyásolja (Molnár et al. 2010). Ezért is írhatták a szerzők az Agrárgazdasági Kutatóintézet 2010-ben a vidékfejlesztési politika gyakorlatáról szóló tanulmányában, hogy a beavatkozások hatásbecslésének első lépése után (ami a közvetlen eredmények számbavételét jelenti), „az értékelő a program által érintett terület szintjén az általános tendenciához (...) való hozzájárulás becslését végzi, amennyiben a program hatása az egyéb tényezökhöz mérten statisztikailag kimutatható. Amennyiben ez nem lehetséges, (...) általános keretek között minőségi vizsgálatot végez" (Molnár et al. 2010,32.).

A 2004-es EU-s csatlakozást követően a magyar gazdaságba jelentős támogatás érkezett fejlesztési céllal (Balogh 2012), amely a hazai gazdaság- és társadalomfejlesztési programok első számú forrásává vált (Szabó et al. 2016). A 2007 és 2013 közötti EU-s költségvetési ciklus során hazánk számára 8000 milliárd forintot ítéltek meg (Európai Bizottság 2008), amelyből mai árfolyamon számolva 500 milliárd forint közvetlenül mezőgazdasági-vidékfejlesztési célú volt (Európai Bizottság 2009). Az Európai Mezőgazdasági Vidékfejlesztési Alapból származó források felhasználására készített Új Magyarország Vidékfejlesztési Program négy kiemelt fejlesztési célterületet nevezett meg, amelyet a vidékfejlesztés négy tengelyének hívott (VM 2007). A tervek szerint a források egyaránt szolgálták a me- 
zőgazdaság versenyképességének (1. tengely) emelését és fenntarthatóságának (2. tengely) megőrzését, valamint az agrárgazdálkodáson kívüli vidéki gazdaság fejlesztését, illetve a vidéki társadalom, kultúra és közösségek (3. tengely) támogatását. A kifejezetten társadalmi célú fejlesztések között kulcsszerepet töltött be a vidéki térségek gazdasági struktúrájának átalakítása, új vállalkozások létrehozása és fejlesztése, továbbá a helyi szolgáltatások támogatása, összességében a helyi életminőség javítása. A stratégia a „foglalkoztatás, gazdasági és vállalkozói aktivitás, illetve jövedelmi viszonyok javítását" (VM 2007, 83.) gazdasági szerkezetváltoztatással kívánja elérni, és első helyen a vállalkozásfejlesztéseket, a diverzifikációt, ezen keresztül pedig a munkahelyteremtést nevezi meg.

A mezőgazdasági és ipari termelés háttérbe szorulásával jellemezhető gazdasági szerkezetváltozás Magyarországon, s ezzel együtt Közép-Európában, noha hosszú távon szemlélve fokozatosan ment végbe, a rendszerváltozáskor, az államszocialista ipar leépülésével hirtelen vált nyilvánvalóvá (Kolosi, Róbert 2004). A vidéki térségekben élő népesség, amelynek arányát a hazai iparosodás késleltetett voltával szokás magyarázni (illetve azzal, hogy emiatt az urbanizáció az indusztrializációval nem volt képes lépést tartani) (Enyedi 2011), a hazai átlagnál sokkal inkább megszenvedte a rendszerváltás okozta kedvezőtlen gazdasági és munkaerőpiaci változásokat. A mezőgazdaság megszűnt a vidéki térségek domináns gazdasági ágazata lenni (Juhász 2006), az ipar pedig tőkekoncentráció-igénye miatt soha nem is lehetett az. Nem csoda hát, hogy a vidékfejlesztési elképzelések - s ezen belül az ÚMVP is - a gazdasági szerkezetváltozást, a mezőgazdasági termelés helyett a szolgáltató szektor fejlesztését tartotta a legfontosabb társadalmi céljának (VM 2007).

A rendszerváltás óta eltelt évtizedekben a magyar vidék társadalmilag is diverzifikálódott, egyes, kedvező elhelyezkedésű vagy jó adottságokkal rendelkező térségek képesek voltak gazdaságot átalakító lépések megtételére, vagy részt vettek az ezredforduló környékére kibontakozó szuburbanizációs folyamatokban. A vidéki térségek nagy részén azonban olyan kedvezőtlen gazdasági-társadalmi folyamatok indultak meg, amelyek következtében a kistelepüléseken élők rendkívüli hátrányba kerültek (Kovách 2012). A települések típusa helyett a települések földrajzi elhelyezkedése vált meghatározóvá a társadalmi egyenlőtlenségek szempontjából: a magyar lakosság harmadát kitevő, községben élő népesség periferiális helyzetű, rossz infrastrukturális és munkaviszonyokkal, kedvezőtlen jövedelmi helyzettel rendelkező többsége teljesen leszakadt (Valuch 2015; Virág 2010). A foglalkoztatók vidéki hiánya mellett az európai összehasonlításban nagyarányú vidéki népesség munkaerőpiaci pozícióit tovább gyengíti az ingázás nehézkessége: noha a megfelelő helyi munkalehetőségek hiánya miatt (Lakatos, Váradi 2009) a községekben élők fele ingázik - amelyből 5 százalékpontot jelentenek csupán a Budapestre ingázók (KSH 2016) -, arányuk a községek teljes társadalmában egyre csökken (Kovács, Egedy, Szabó 2015). A községekben élők gazdasági és munkaerőpiaci helyzetének értékelésekor tehát az ingázás bevonása kihagyhatatlan, különösen, ha vizsgálatunk települési szintű. 


\section{Korábbi vizsgálatok}

Az EU-s fejlesztési támogatások általános és szűkebb értelemben vett (tehát nem a közvetlen eredmények, outputok puszta számbavételén alapuló) hatáselemzéseinek száma csekély, nem csupán a hazai, de a nemzetközi szakirodalomban is, s különösen igaz ez a vidékfejlesztési támogatásokra (Fertő, Varga 2015). Főleg adathiány miatt a fejlesztési programokat nem tudják értékelni a szakpolitika szempontjai szerint (Adedokun, Childress, Burgess 2011; Vidueira et al. 2015; Yang et al. 2015). Jellemző, hogy a vidékfejlesztési támogatások hatásait elemző tanulmányok esettanulmányi jellegűek, amelyekből nem lehet általános érvényű megállapításokat levonni (Nijkamp, Blaas 1995). Az Európai Bizottság dokumentumai a vidékfejlesztési eszközök felhasználásának eredményességéről számolnak be, vagyis azt mutatják, hogy a gazdasági-társadalmi mutatók a szakpolitikai elképzeléseknek megfelelő irányban változnak. Ezek az elemzések azonban egyes (országos vagy NUTS2 régió szintű) mutatók változásáról számolnak be, a magyarázó tényezők vizsgálatára nem térnek ki. Hasonló jelentések országok szintjén is készültek (Magyarország esetében például ÁSZ 2012; KPMG 2017; VÁTI 2004), azonban, amint arra Andersson, Höjgård, Rabinowicz (2017) rámutatnak, ezek gyakran - módszertani okokból - nem alkalmasak megalapozott következtetések levonására, s ezért eredményeiket sok esetben nem is lehet figyelembe venni a későbbi tervezési folyamatok során.

A korábbi EU-s regionális vagy vidékfejlesztési források, illetve programok hatáselemzésével foglalkozó tanulmányok között akadnak az oksági kapcsolatok alaposabb feltárásával készült kutatások is. Kiemelt figyelmet fordítottak az elemzők egy-egy úttörő programra, így például a helyi termékek és védjegyek hatásaira (Cei, Defrancesco, Stefani 2018; Landi, Stefani 2015; Parasecoli, Tasaki 2011), vagy az endogén helyi fejlesztés „kísérleti” programjára, a LEADER programra (Barke, Newton 1997; Bosworth et al. 2016; Esparcia Perez 2000; Papadopoulou, Hasanagas, Harvey 2011). A területi és vidékfejlesztési források általános hatáselemzése esetén kihívást jelent, hogy e programok szándékuk szerint a gazdaságitársadalmi élet számtalan aspektusára egyszerre szeretnének hatást gyakorolni. Ennek megfelelően hatásosságuk felmérésére több komplex mutatót és indexet használnak. Nijkamp és Blaas (1995) viszonylag egyszerű, de a fejlesztések több aspektusát megragadni képes modellt dolgozott ki a regionális fejlesztési támogatások hatáselemzéséhez, és ennek használhatóságát mutatta be Hollandia példáján. Yang et al. (2015) - az Európai Unió által ajánlott közös monitoring és értékelési keretrendszer (CMEF) alapján - ennek korlátait felismerve, területalapú gazdaságelemzési és mikroszintủ elemzési módszereket véve alapul - alakítottak ki átfogó vidékfejlesztési programértékelési módszertant. Michalek és Zarnekow (2012) kompozit indexet állított össze a vidéki gazdasági-társadalmi fejlettség mérésére, amelyet Szlovákia NUTS4 szintủ régióinak példáján alkalmazott.

Ezt a modellt - a magyarországi adatok elérhetősége szerint átalakítva és kiegészítve - a 2002 és 2008 közötti időszak fejlesztési hatáselemzésére magyar 
kutatók is felhasználták (Bakucs et al. 2018; Fertő, Varga 2015). Kutatásukban kísérleti elrendezésben (ahol a kontrollt azon területek alkották, amelyek nem részesültek fejlesztési támogatásban) sikerült feltárni a fejlesztési források sokszor ellentmondásos hatásait, még ha ezek a hatások nehezen megfigyelhetők és gyengék voltak is. A HÉTFA Kutatóközpont (Balás et al. 2015), illetve Molnár et al. (2010) átfogóan vizsgálta a magyar fejlesztési források felhasználásának eredményességét. Noha a vidékfejlesztési támogatásokkal nem foglalkoztak elemzésükben, Balás et al. (2015) a fejlesztési támogatások makrogazdasági mutatókra gyakorolt hatásait kvalitatív és kvantitatív módszerekkel elemezve megállapítják, hogy a foglalkoztatottak számát közvetlenül (beruházások generálásán keresztül) és közvetetten is pozitívan befolyásolják, de szakértői vélemények alapján a hátrányos helyzetü térségekben e hatásuk nem érvényesül. Molnár és szerzőtársai (2010) - kvalitatív kutatás mellett - a 2003-tól 2009-ig tartó időszakban a fejlesztési támogatások (ezen belül a vidékfejlesztési támogatások) mértékét és különböző gazdasági-társadalmi mutatók változását vizsgálták kistérségi szinten. Arra a következtetésre jutnak, hogy a vidéki térségekben élők lehetőségeire kedvező hatást gyakoroltak a közlekedési infrastruktúrafejlesztések, és a falusi idegenforgalom is növekedést mutatott. Megjegyzik ugyanakkor, hogy a vidéki gazdaságfejlesztés, diverzifikáció hatása makroszinten nem mutatható ki ebben az időszakban.

\section{Problémafelvetés}

A vidékfejlesztési vagy térségi fejlesztési programok hatáselemzésének két nagy akadályát látjuk tehát:

- Egyrészt nehezen lehet kísérleti szituációt alkalmazni a programok mérésére, mivel a kontrollcsoport nehezen határozható meg (például matching módszerrel, ahogyan azt Fertő, Varga 2015 tette) vagy nem létezik; dichotóm változó indikátorként nehezen használható.

- Másrészt a programok rendkívül sokfélék, nem beszélhetünk azonos kezelésről sem, amennyiben a fejlesztési elképzeléseket projektszinten értékeljük.

A klasszikus kísérleti módszerek mellett számos más eszköz rendelkezésünkre áll. Ilyen például - legújabban magyar kutatásban is használt - a becsült részvételi valószínűségen alapuló párosítás (generalized propensity score matching), amely megpróbálja kiküszöbölni azt a problémát, hogy a kezelési hatás skálán mérhető (Bakucs, Fertő, Benedek 2019). További módszer a lineáris regresszión alapuló útmodellezés. Ez nemcsak arra alkalmas, hogy a függő változót a vizsgálatba bevont más változók függvényében láttassa, hanem arra is, hogy rávilágítson egyes látens mechanizmusokra (Astbury, Leeuw 2010). Ennek megfelelően pedig ne csak arra adjon választ, hogy létezik-e összefüggés magyarázó és függő 
változó között, hanem arra is, hogy ez a kapcsolat milyen struktúrában, hogyan működik (Adedokun, Childress, Burgess 2011). Természetesen ennek az előnynek ára is van: mivel a változók közötti összefüggésrendszer több permutációban felírható, így a kutató egyik legfontosabb feladatává az válik, hogy érvényes elméleti struktúrát alkalmazzon (Smith 1990).

A tanulmányban az Új Magyarország Vidékfejlesztési Program (2007-2013) hatásait vizsgálom abból a szempontból, hogy a programban megfogalmazott társadalmi célok hogyan teljesültek (VM 2007, 4.1.3. fejezet). A program - a mezőgazdasági célok bemutatását követően - a harmadik és negyedik tengelyes források felhasználásának célrendszerében foglalkozik a társadalmilag fontos célokkal. „Az alacsony foglalkoztatottsági szint, az elégtelen gazdasági és vállalkozói aktivitás, valamint a jövedelemszerzési lehetőségek javithatók a gazdasági szerkezetváltáson keresztül, amely növekvő számú és versenyképesebb vállalkozások megjelenését eredményezi, valamint magasabb foglalkoztatottsági szintet és jobb jövedelemszerzési lehetőségeket" (VM 2007, 83.). Ennek a feltételezésnek megfelelően azt vizsgálom, hogy az ÚMVP harmadik tengelyes kifizetései miként tudtak hozzájárulni a vállalkozások és a foglalkoztatottak számának növelésén keresztül a jövedelmi viszonyok javulásához.

Megközelítésem három szempontból tartható újszerünek:

- A 2007-2013-as EU-s költségvetési ciklusban megvalósult magyarországi vidékfejlesztés társadalmi hatáselemzésére ez idáig alig került sor, így az elemzés hiánypótló.

- A rendelkezésre álló adatok lehetőséget adtak a településszintű vizsgálatra.

- Kontroll- és kísérleti csoport elkülönítésén alapuló kísérleti elrendezés helyett az elemzéshez lineáris regresszión alapuló útmodellezést használtam. Így megkülönböztethetők a fejlesztési támogatások közvetett és közvetlen hatásai és az összefüggésrendszer strukturálható. Ez ugyan nem tekinthető innovatív megoldásnak (Smith 1990), valamint skálaszintü kezelési hatással is kísérleteztek - magyar kutatásban Bakucs, Fertő, Benedek (2019) -, útmodellezéssel történő hasonló elemzést még nem végeztek. Tekintve, hogy a magyarázó és függő változó is skála mérési szintű, kézenfekvő a lineáris regresszió, kísérleti jellegű elemként pedig a longitudinális változást megragadó változók használata.

Forrásként a Magyar Államkincstár (fejlesztési támogatások), a Központi Statisztikai Hivatal (idősoros népességszám, ingázók aránya, idősoros regisztrált vállalkozások száma), a Nemzeti Adó- és Vámhivatal (idősoros jövedelmi viszonyok, idősoros foglalkoztatottak száma) adatait használtam. Ezek az adatok minden településre elérhetők az Országos Területfejlesztési és Területrendezési Információs Rendszerben. A kutatás során csak (a 2007-es státuszuk szerinti) községekkel foglalkoztam, és megkülönböztettem az agglomerációs és a nem agglomerációs településeket. Azokat a községeket tartottam agglomerációsnak, amelyeket a KSH (2014) agglomerációk vagy településegyüttesek köré- 
be sorolt ( $\mathrm{n}=471$ ). Hasonlóképpen kiemeltem a 311/2007. (XI.17.) kormányrendelet által leghátrányosabb helyzetủ kistérségekbe (LHH) sorolt mikrorégiók községeit ( $\mathrm{n}=644)$ (1. ábra).

Az alminták önálló kezelésére a gazdasági lehetőségek eltérő elérhetősége miatt van szükség. A korábbi kutatások (Bakucs et al 2008; Fertő, Varga 2015; Lakatos, Váradi 2009; Vidueira 2015) ugyanis a fejlesztési támogatások eltérő működési formáit mutatták ki, vagyis feltételezhető, hogy a szűkebb értelemben vett vidékfejlesztési támogatások nem azonos hatásúak a kedvezőbb és kedvezőtlenebb gazdasági-munkaerőpiaci helyzetű területeken. Hasonlóan fontos a szuburbiák megkülönböztetése. Az agglomerációs térségek településeivel foglalkozó magyar kutatások közös álláspontja, hogy a települések földrajzi elhelyezkedése és térségi kapcsolatai az egyenlőtlenségek egyik legfőbb meghatározója. A funkcionálisan a városokhoz kapcsolódó szuburbiákban másfajta munkaerőpiaci logika érvényesül, mint a városoktól távol eső községekben. Magyarországon a társadalmi különbségek területi szinten, EU-s összehasonlításban is rendkívül jelentősek (Csurgó 2013; Csurgó et al. 2017).

\section{1. ábra: A vizsgált magyarországi települések csoportjai} Settlement groups of the analysis

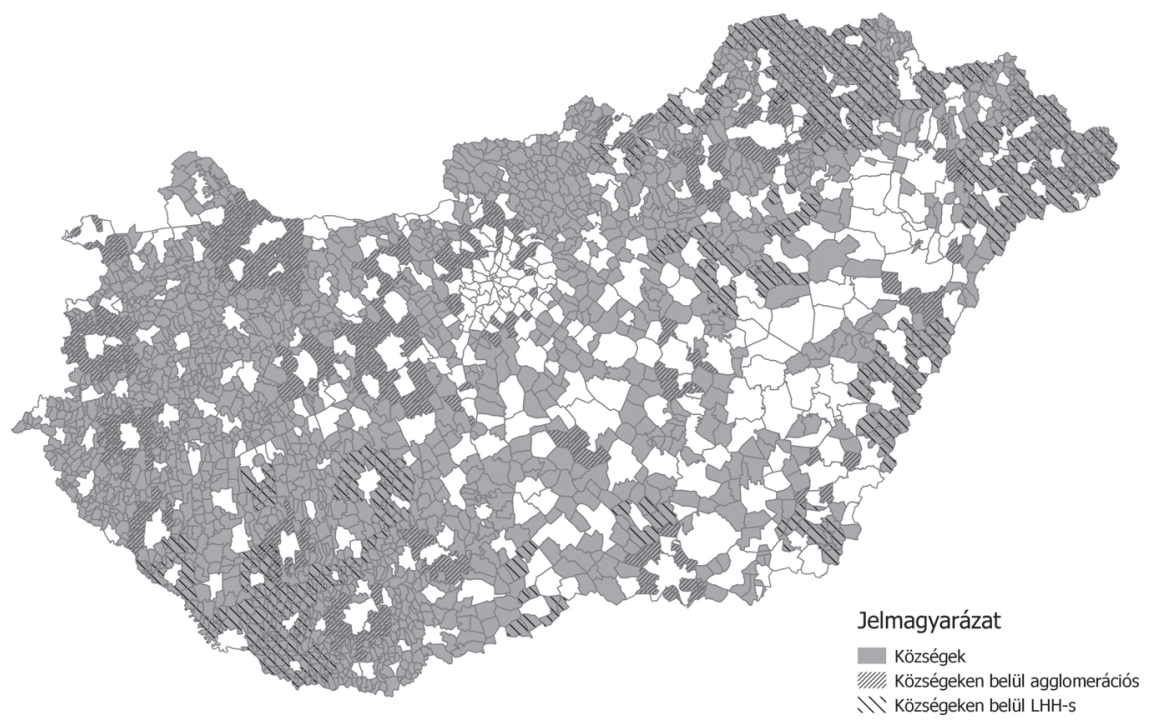

\section{Modellstruktúra és felhasznált változók}

A modell az ÚMVP vidéki gazdaságfejlesztési célkitűzésén alapul (harmadik tengelyes, nem mezőgazdasági célú vidékfejlesztési támogatások): „az alacsony 
foglalkoztatás, gazdasági és vállalkozói aktivitás, illetve jövedelmi viszonyok javítása a több és versenyképesebb vállalkozást, a nagyobb foglalkoztatást és a jobb jövedelmezőséget eredményező gazdasági szerkezetváltással érhető el. Ehhez a vállalkozóvá válás ösztönzésére, a mikrovállalkozások helyzetének javítására (...) irányuló fejlesztések szükségesek" (VM 2007, 83.)

A gazdasági szerkezetváltozás nehezen operacionalizálható. A stratégia fordított logikai kapcsolatrendszerrel dolgozik, ugyanis a gazdasági szerkezetváltozást - deduktív logikával - eszközként értelmezi, jóllehet az a (tercier szektorbeli) vállalkozások számának, illetve a foglalkoztatottság növekedésének eredményeként, a stratégia hosszú távú céljaként is felfogható (mint ahogyan arra utal is a program). Amellett, hogy a vállalkozások megjelenése inkább indikátora, semmint következménye a szerkezetváltozásnak, az az állítás is könnyen értelmezhető, hogy a szolgáltató szektor támogatása növeli a vállalkozásalapítási kedvet, a foglalkoztatottságot és javítja a jövedelmi helyzetet. A szerkezetváltozásra vonatkozó stratégia egyszerre hivatkozik ugyanazon változók okára és okozatára. A gazdasági szerkezetváltozás, a vidéki gazdaság diverzifikálása az ÚMVP harmadik intézkedéscsoportjának fő célkitűzése, amelyet a harmadik tengelyes támogatásokkal tervez elérni a stratégia (VM 2007).

A támogatások - mint magyarázó változók - közvetlen és közvetett hatásait vizsgálom a jövedelemszerzési lehetőségekre, amely a stratégia életminőséget javító végső célja. Köztes változóként a mikrovállalkozások és a foglalkoztatottak száma szerepel a modellben. A munkaerőpiac magyarországi térségi struktúrája ismeretében (Kovács, Egedy, Szabó 2015; KSH 2016; Lakatos, Váradi 2009) az ingázók arányának figyelembevételére is szükség van.

A szakpolitikai állítások magyarázata alapján a kutatás hipotézisei:

- A magyarországi községekben a szűkebb értelemben vett vidékfejlesztési támogatások képesek voltak hozzájárulni a helyi mikrovállalkozói szféra bővüléséhez, a foglalkoztatottak arányának emelkedéséhez, illetve ezeken keresztül a helyi jövedelmi helyzet javulásához.

- A pozitív hatások a hátrányos helyzetú településeken jobban érvényesülnek, mint másutt.

- A pozitív hatásokat befolyásolja a falvak településszerkezeti elhelyezkedése, a nagyvárosok közelsége.

A változók közötti kapcsolatok irányítására is szükség van a három köztes változó esetén. A mikrovállalkozások és a foglalkoztatottak közötti oksági kapcsolat mindkét irányban működhet, mivel a foglalkoztatottág növekedése bővülő keresletet generálhat a vállalkozások szolgáltatásaira, ugyanakkor a vállalkozások munkahelyeket teremthetnek a helyiek számára. Minthogy az ÚMVP szakpolitikai elképzeléseiből kiindulva ezt a „tyúk vagy tojás” helyzetet nem lehet megoldani, abból a megfontolásból, hogy az utóbbi hatás rövidebb távon is érvényesül, feltételezem, hogy a kapcsolat iránya a változók között ennek megfelelő lesz. Az ingázók modellbe foglalását több ok miatt is óvatosan kell kezelni. Míg a többi függő változó esetén a 2007-2013-as ciklusban változó értékű megfigyelés lehet- 
séges, addig az ingázási adatok települési szinten csak a népszámlálás évére érhetők el, ami sokkal inkább a térségi kapcsolatok szükséges, de általános indikátoraként kerül a modellbe. Kérdés az, hogy mennyire tud érvényesülni a fejlesztési támogatások vállalkozás- és foglalkoztatottságösztönző hatása alacsonyabb és magasabb ingázási arány mellett. Így fordított logikával a térségi kapcsolatokat jelölő ingázási arány a vállalkozások és foglalkoztatottak számát magyarázó változóként értelmezi.

A modellben felhasznált változók (a leíró statisztikákat lásd a függelékben):

- Támogatások: A Magyar Államkincstár adatbázisából településsorosan elérhető, 2007 és 2014 között kifizetett vidékfejlesztési (ÚMVP-EAFRD) támogatások összesített értéke a harmadik tengelyen, egy állandó lakosra (a 2007. évi lakosságszám szerint). A harmadik tengelyes támogatások egy före jutó kifizetése a ciklusban, nagy szóródás mellett, átlagosan 58 ezer forint volt, az agglomerációs községekben ennél az átlagnál jóval alacsonyabb (43 ezer forint), a hátrányos helyzetű térségekben jóval magasabb (97 ezer forint).

- Mikrovállalkozások: Az 1-9 fős vállalkozások egy lakosra jutó számának változása 2006 és 2016 között (KSH). A 2006 és 2016 közötti időszak oka, hogy a 2007-2013-as költségvetési ciklust megelőzó év értékét a ciklus során folyósított kifizetések lezárulását követő év adataival volt célszerü összevetni. Minthogy 2015-ben még dokumentáltak ÚMVP-kifizetéseket, 2016 volt az első olyan év, amelyben e ciklus „hatása” már nem érvényesülhetett közvetlenül. Az 1-9 fős vállalkozások egy före vetített aránya átlagosan 7,6\%-kal bővült.

- Foglalkoztatottak: fóállásúak egy lakosra jutó számának változása 2006 és 2016 között (KSH). A fóállásúak aránya a leghátrányosabb helyzetű településeken bővült legjobban, 11,5\%-kal, míg a községek átlaga ennél valamivel alacsonyabb, $9 \%$ volt.

- Ingázók: a naponta ingázó foglalkoztatottak aránya a település foglalkoztatottainak körében (2011-es népszámlálás, KSH). Ez az arány az agglomerációs községekben 75\%-os, más községekben 60\%-os, az LHH-s kistérségek községeiben pedig csupán 49\%-os volt.

- Jövedelem: a településen élők főállásból származó jövedelmének (NAV) egy állandó lakóra vetített értékének változása 2006 és 2014 között. 2006-os értéken az egy lakosra jutó jövedelmek 79 ezer forinttal bővültek, ez az érték mind az agglomerációs, mind pedig a leghátrányosabb térségek községeiben magasabb.

\section{Eredmények}

Az agglomerációs községek ( $n=471)$ almintáján végzett útmodellezés nem eredményezett nagy magyarázó erejü modellt. A standardizált $\mathrm{R}^{2}$-érték mindössze 
0,04, vagyis a magyarázó változók az egy főre eső jövedelemváltozás értékének szóródásából csupán 4\%-ot képesek megmagyarázni. A kiemelt kapcsolatok az 5\%-nál alacsonyabb p-értékủ regressziós együtthatókkal leírható lineáris kapcsolatokat jelölik, minden esetben a standardizált $\beta$-értékeket tüntettem fel (2. ábra). Az egyenletek illeszkedési és meredekségi mutatóit, illetve a p-értékeket a függelék tartalmazza.

Nem meglepő, hogy az agglomerációs települések esetén a vidékfejlesztési támogatások közvetlenül és közvetve kevésbé hatnak a jövedelemváltozásra. Ezek a települések funkcionálisan a nagyvárosokhoz tartoznak, a jövedelemszerzési lehetőségek kevésbé a helyben elérhető vállalkozásoktól, sokkal inkább attól a várostól függnek, amelynek környezetében helyezkednek el. A jövedelmi helyzetet befolyásoló hatások a változókészleten belül kizárólag a foglalkoztatottak arányának javításán keresztül érvényesülnek. Ez az összefüggés fennáll valamennyi vizsgált községtípus esetén, vagyis azt mondhatjuk, hogy a foglalkoztatottak arányának növekedésén keresztül hatékonyan lehet növelni a településen élők jövedelmi helyzetét. Ez a kijelentés magától értetődőnek hangozhat, azonban egyáltalán nem az. Ahhoz, hogy az állítás igaz lehessen, két feltételből legalább az egyiknek teljesülnie kell: vagy az újonnan létrejövő munkahelyeknek korábban inaktív vagy munkanélküli helyi lakókat kell bevonzania (ne felejtsük, a jövedelmet nem a foglalkoztatottak számához, hanem a teljes népességhez arányosítottuk), vagy magasabb fizetést kell biztosítania a korábbi átlagfizetéshez képest.

$\mathrm{Az}$ egy főre eső harmadik tengelyes vidékfejlesztési támogatások pozitív hatása a mikrovállalkozások (lakosságszámhoz viszonyított) arányának növeke-

2. ábra: Az agglomerációs községek almintáján végzett útmodellezés

(zárójelben a standardizált regressziós együtthatók)

Path analysis on the subsample of agglomeration villages (with standardised regression coefficients)

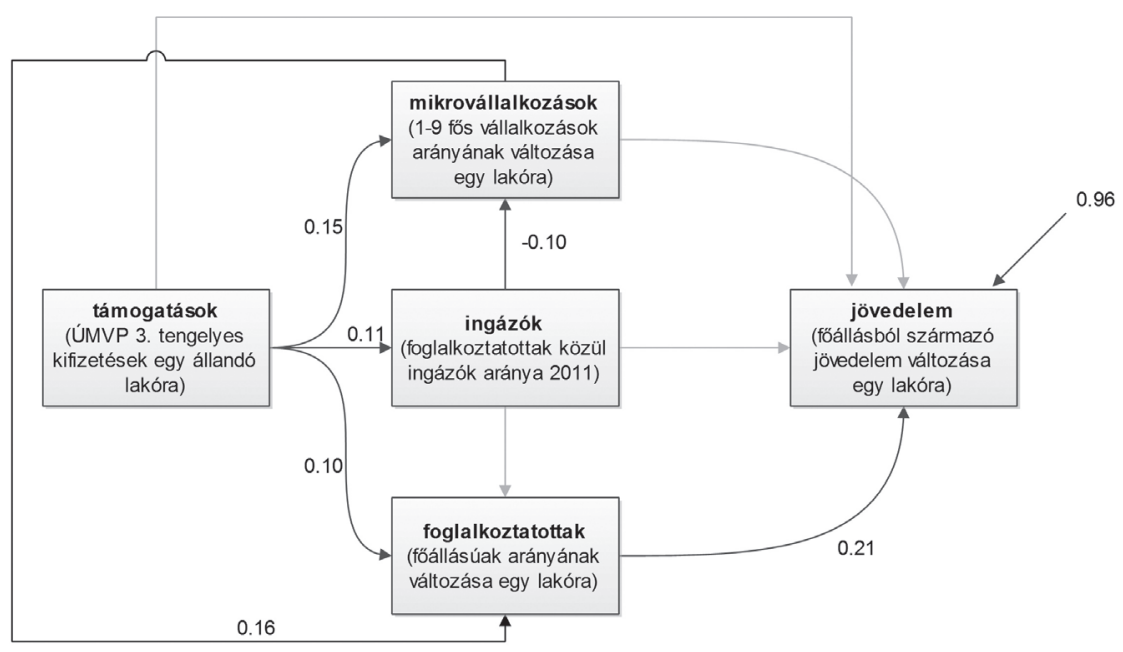


désére az agglomerációs és a nem agglomerációs községek, illetve az LHH-s községek mintáján is kirajzolódik. Ez azt jelenti, hogy a támogatásokkal mindenhol sikerült növelni a mikrovállalkozások számát. A korrelációs számítások hasonlóan pozitív összefüggést mutatnak a támogatások és a nagyobb (maximum 49 fós) vállalkozások arányának növekedése között is, ám az ilyen vállalkozások alacsony száma miatt az összefüggés kevésbé megbízható. Az agglomerációs községek mintáján az utak 1\%-nál alacsonyabb p-értékü strandardizált regressziós $\beta$-értékeit összeadva $0,15 \times 0,16 \times 0,21+0,11 \times(-0,10) \times 0,16 \times 0,21+0,1 \times 0,21=0,026$-os összesített értéket kapunk, vagyis a szűkebb értelemben vett vidékfejlesztési források közvetett jövedelembefolyásoló hatása alig vehető észre.

A nem agglomerációs községek $(\mathrm{n}=2337)$ azonos változóstruktúrával végzett útmodellezése magasabb magyarázó erejü, az egy lakosra jutó jövedelemváltozásnak „mindössze” 78\%-át nem sikerült ezzel a változókészlettel megmagyarázni (3. ábra). A modellben megjelenik a harmadik tengelyes támogatások közvetlen hatása is a jövedelemváltozásokra, amelyet betudhatunk a támogatott projektek végrehajtásából származó rövid távú és közvetlen jövedelemnövelő hatásnak (Molnár et al 2010), függetlenül attól, hogy ismernénk a jövedelmek szórását a foglalkoztatottak körében. A nem agglomerációs települések esetén - s az összefüggés hasonlóan igaz az LHH-s kistérségek községeinek almintájára is - a mikrovállalkozások arányának változása szintén pozitív összefüggésben áll az átlagjövedelmi helyzet változásával, s így a támogatások közvetetten is hatnak a vállalkozásösztönzésre. Ez egészül ki a foglalkoztatottak számának növelésére gyakorolt hatással (amelyet az agglomerációs települések mintáján már tapasztaltunk).

3. ábra: A nem agglomerációs községek almintáján végzett útmodellezés

(zárójelben a standardizált regressziós együtthatók)

Path analysis on the subsample of non-agglomeration villages

(with standardised regression coefficients)

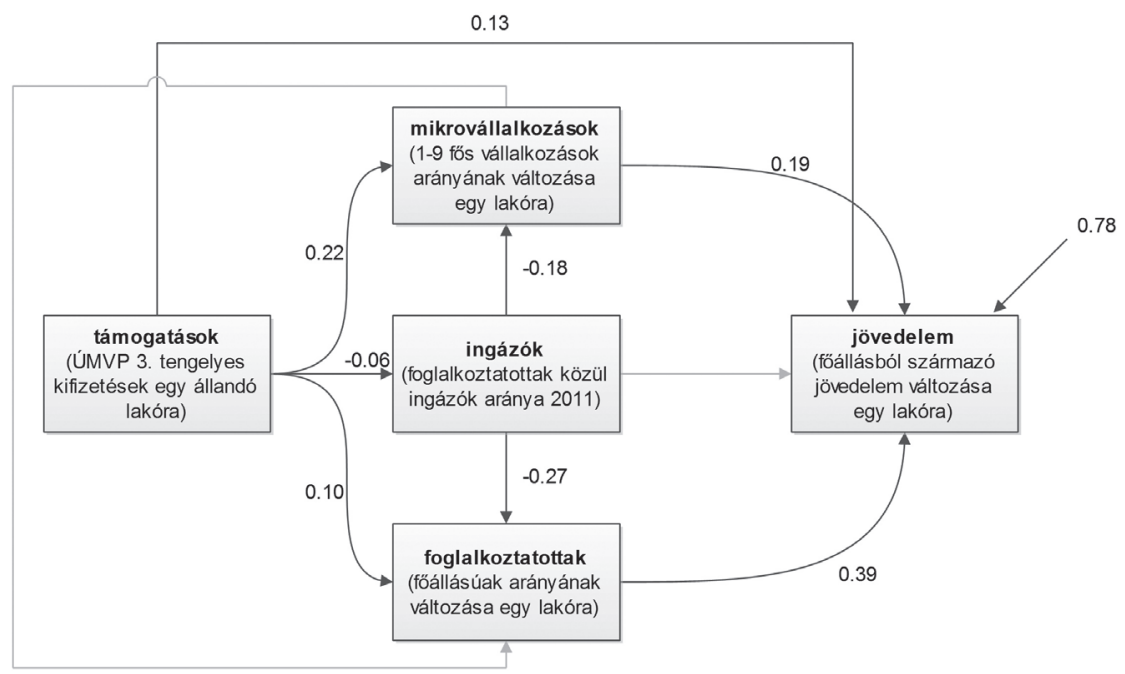


Az ingázók arányának mutatóját azért volt szükséges beilleszteni a modellbe, mert így ragadható meg a községek térségi kapcsolati helyzete; a foglalkoztatottak körében mért ingázási arány a közeli városok vonzó hatásának indikátora. Ez a változó ugyanakkor „kakukktojás” is, hiszen a többi függő változóval ellentétben nem változást mér, hanem a 2011. évi állapotról nyújt keresztmetszeti képet, így modellbeli jellemzőit is ennek megfelelően kell értelmeznünk. Az agglomerációs községek körében a támogatások pozitív összefüggésben állnak az ingázók arányával, vagyis a harmadik tengelyes támogatások a munkavállalók számára növelik a városok vonzerejét az agglomerációs községekben. Ezzel ellentétben a nem agglomerációs, illetve LHH-s községek almintáján a 6-8 százalékos standardizált $\beta$-értékek rendkívül gyenge negatív összefüggést jelölnek, alacsony p-értékek mellett.

Érdekes, hogy valamennyi községtípus esetén számottevő negatív összefüggés mutatható ki az ingázók és a mikrovállalkozások aránya között. Ez azt jelenti, hogy a nagy vonzerővel rendelkező (közeli) városok jelenléte maga után vonja a helyi vállalkozások csökkenő (helyi népességszámra vetített) számát. Az ingázók aránya és a foglalkoztatottak arányváltozása között hasonló negatív kapcsolat áll fönn a nem agglomerációs településekben: a közeli városok szívóhatása megmutatkozik a foglalkoztatottak számának csökkenő arányában. Ez utóbbi összefüggés sem az agglomerációs, sem a leghátrányosabb helyzetủ településeken nem érvényesül, vagyis a kedvezőbb vagy kedvezőtlenebb térségi helyzet nem meghatározó. Azokban a községekben, ahol az ingázási arány magasabb volt, a foglalkoztatottak aránya kisebb mértékben bővült. Ennek oka az lehet, hogy ezekben a térségekben a foglalkoztatás bővülése a térségi kapcsolatoknak köszönhetően telítettségi szintet ért el. Viszont azokban a községekben, ahol az ingázók aránya alacsonyabb volt, az ingázások arányának növekedésével tudott bővülni a foállásúak népességen belüli aránya. ${ }^{1} \mathrm{Ez}$ az összefüggés az agglomerációban és az LHH-s kistérségek községeiben azért sem érvényesülhet, mert ezek térségi kapcsolati szempontból homogénebbek: az agglomerációban a viszonylag kedvezőtlen térségi kapcsolati helyzetben is eleve magas az ingázói arány, ${ }^{2}$ a leghátrányosabb helyzetű térségek aktív népessége sem képes nagyobb arányban ingázni az általánosan kedvezőtlen szociális, infrastrukturális helyzet miatt. A nem agglomerációs községek esetén a fejlesztési támogatások közvetlen hatását $(0,13)$ szintén pozitív előjelü, közvetetten érvényesülő 0,076 -os erősségü hatás egészíti ki, s így összességében $0,13+0,22 \times 0,19+(-0,06) \times(-0,18) \times 0,19+$ $+(-0,06) \times 0,27 \times 0,39+0,1 \times 0,39=0,206$-as érték mutatja, hogy a fejlesztési támogatások a foglalkoztatottak és a vállalkozások arányának növelésén keresztül is jól látható módon befolyásolják a jövedelmi helyzetet.

A leghátrányosabb helyzetű kistérségek községeinek ( $\mathrm{n}=644)$ almintáján ${ }^{3}$ végzett útmodellezés a legmagasabb, 27\%-os magyarázó erejü (4. ábra). A nem agglomerációs községekhez hasonlóan az LHH-s községekben a támogatások - közvetlenül és közvetetten - a mikrovállalkozások arányának növelésén keresztül pozitívan befolyásolják a helyi jövedelmi viszonyokat. Két, korábban nem tár- 
4. ábra: Az LHH-s kistérségekben elhelyezkedő községek almintáján végzett útmodellezés (zárójelben a standardizált regressziós együtthatók)

Path analysis on the subsample of villages of the 33 least developed microregions (with standardised regression coefficients)

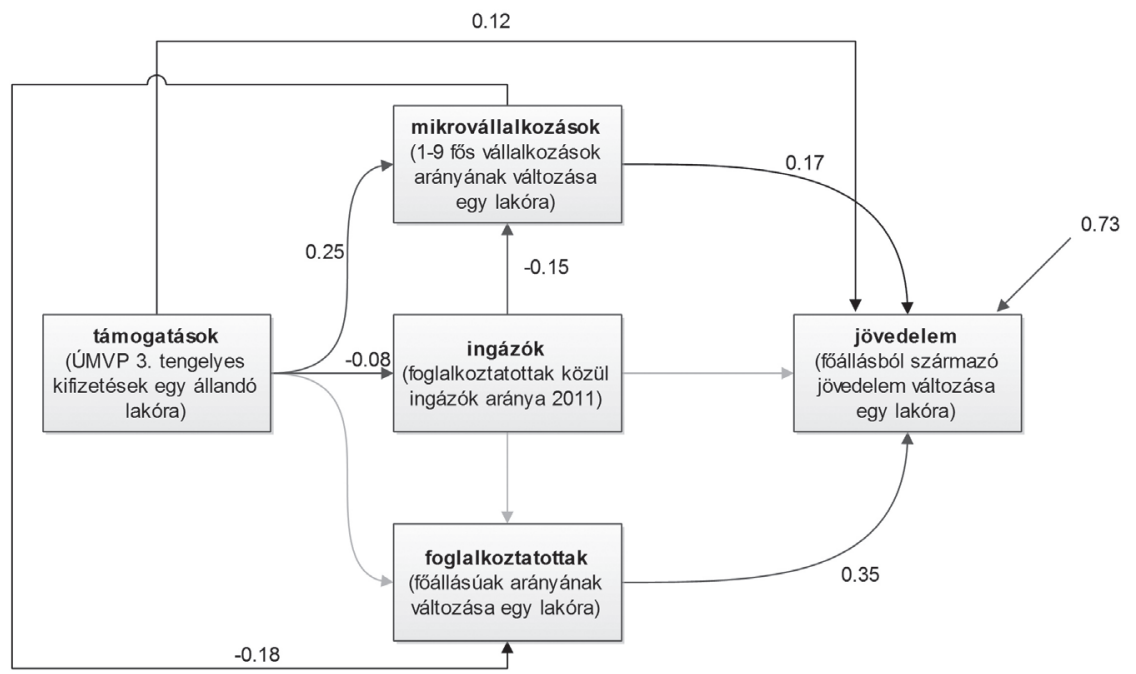

gyalt összefüggést érdemes kiemelni. Egyfelől, a leghátrányosabb helyzetű községekben eltünik a támogatások foglalkoztatottak számára gyakorolt közvetlen pozitív hatása. A kifizetett harmadik tengelyes vidékfejlesztési támogatások egy főre vetített értéke azonban közvetetten negatív módon befolyásolja a fóállású foglalkoztatottak egy lakosra vetített arányának változását 2006 és 2016 között. A vidékfejlesztési támogatások összességben - mivel a foglalkoztatottak arányának változása az egy főre eső jövedelem változásával ezúttal is pozitív kapcsolatban áll - negatív módon befolyásolják a jövedelmi viszonyokat. Az LHH-s községek almintájában is igaz, hogy a fejlesztési támogatások - közvetlen hatásaik mellett - közvetett módon is pozitívan változtatnak a foglalkoztatottak jövedelmi helyzetén, ám a negatív előjelü köztes kapcsolatok miatt ez a közvetett hatás nem jelentős, és csupán 0,029-es, alig észrevehető értékkel egészíti ki a közvetlen hatást. Az LHH-s településeken összesen $0,12+0,25 \times 0,17+$ $+(-0,08) \times(-0,15) \times 0,17+0,25 \times(-0,18) \times 0,35=0,149$-es összesített érték mutatható ki.

Együtt vizsgálva a három útmodellt, eltéréseket láthatunk mind a fejlesztési támogatások és a munkaerőpiaci helyzetet megragadó változók, mind ezek és a jövedelmi helyzet összefüggéseiben.

- Az egyik ilyen eltérés, hogy míg a mikrovállalkozások arányának emelkedése a jövedelmek növekedését eredményezi általánosságban, ilyen hatás nem látszik az agglomerációs községekben. Ennek oka az lehet - Csurgó (2013) véleményét elfogadva -, hogy az agglomerációs községekben a jövedelmi helyzet inkább függ a közeli városok kereseti viszonyaitól, mint a 
helyi vállalkozások számától, jóllehet a helyi foglalkoztatás bővülése is kedvező hatást gyakorol a jövedelmekre.

- A három községi alminta közötti másik fontos eltérés a támogatások közvetlen hatásának hiánya az agglomerációs térségekben. Ennek magyarázata a fejlesztési támogatások kisebb szerepe lehet általában e települések fejlődésében, ugyanakkor azt is jelentheti, hogy ezeken a településeken a meglévő fejlesztési támogatásokat ,jól” vagy „jobban” költik el. Minthogy van (gyenge) közvetett összefüggés a fejlesztési támogatások és a jövedelmek között, azt mondhatjuk, hogy a fejlesztési támogatások jövedelemre gyakorolt hatása az agglomerációs térségek községeiben nem pusztán a projektek megvalósításából, hanem abból fakadt, hogy nagyobb mértékben voltak képesek hozzájárulni a vállalkozások és ezen keresztül a foglalkoztatottak arányának növekedéséhez.

- Minél kedvezőtlenebb térségi kapcsolatokkal rendelkezik egy község, annál kevésbé számítanak a mikrovállalkozások foglalkoztatottságot növelő tényezőnek (a kapcsolat az agglomerációban pozitív, másutt nem észrevehető, a hátrányos helyzetű térségekben negatív). Ezen összefüggés magyarázata arra is választ adhat, hogy mi lehet az oka a harmadik tengelyes támogatások és a foglalkoztatottság közötti kapcsolat hiányának a leghátrányosabb térségekben. Hipotézisem szerint érdemes a közvetett negatív előjelü hatásból kiindulni. A periféria hátrányos helyzetű kistelepülései és a vállalkozások kapcsolatával foglalkozó szerzők hangsúlyozzák a vállalkozások nagyfokú beágyazottságát (Kovách 2012), amely járhat akár negatív következményekkel is, amennyiben hozzájárul a feketefoglalkoztatáshoz, és patrónus-kliens viszonyú foglalkoztatási kultúrát hoz létre (Váradi 2015; Vigvári 2015; Virág 2010). Több szerző rámutat a vállalkozások nehéz helyzetére, ha a változó gazdasági feltételekhez alkalmazkodni képes helyi munkaerőre van szükségük (Bosworth, Farrell 2011; Carlsen, Morrison, Weber 2008). Virág (2010, 91.) a Belső-Cserehát példája kapcsán írja e térségekről, hogy „kedvezőtlen forgalmi helyzetüknek köszönhetően nem, vagy csak nagyon nagy áldozatok árán érhetők el napi ingázással az ipari munkahelyek, s így a foglalkoztatást helyben kell megoldani." Másutt a rendszerváltást követő országos munkaerőpiaci dinamikákkal kapcsolatban így fogalmaz: „Bár (...) létrejött közel egymillió új munkahely, de ide többségében már nem (...) az időben megkopott munkavégző képességű embereket várták" (Virág 2010, 108.). Az LHH-s községek almintáján jelentkező negatív összefüggésre további magyarázat lehet, hogy míg a kedvezőbb adottságú településeken érvényesül a mezőgazdaság korlátozott munkahelyteremtő hatása, addig a hátrányos helyzetű térségekben (például az automatizált termelésre való átállásnak köszönhetően) munkahelyek megszűnésével járhat ez a folyamat. Noha ezek a kijelentések csupán hipotézisként kezelendők, felhívják arra a figyelmet, hogy a vidékfejlesz- 
tési támogatások - még kellően fel nem tárt okok miatt - a várthoz képest eltérő eredményeket hozhatnak.

\section{Összegzés}

A tanulmány az Új Magyarország Vidékfejlesztési Program munkaerőpiaci céljainak megvalósulását vizsgálta a helyi társadalom- és gazdaságfejlesztésben. Lineáris regresszióelemzésen alapuló útmodellezés módszerével vizsgáltam az európai uniós, szűkebb értelemben vett vidékfejlesztési források (3. tengelyes támogatások) felhasználásának közvetlen és közvetett hatását. Az útmodellezéshez a magyar községek településsoros adatbázisát használtam fel, az elemzést az agglomerációs községek, a nem agglomerációs községek, és a „leghátrányosabb helyzetü" 33 kistérség községeinek almintáin végeztem el. Valamennyi községtípus esetén kimutatható volt, hogy a fejlesztési források kedvező hatást gyakoroltak a települések munkaerőpiaci helyzetére, méghozzá nagyjából annak a logikai struktúrának mentén, amelyet a fejlesztési program elképzelt. A kedvező hatás különösen a nem agglomerációs települések almintáján volt meggyőző, ide értve a leghátrányosabb helyzetű térségek községeit is, míg az agglomerációkban a fejlesztési támogatások és a helyi vállalkozások hatása kevésbé meghatározó tényező a jövedelmek alakulásában.

Ugyanakkor az elemzés eredményei azt mutatják, hogy a fejlesztési források munkaerőpiaci hatásai nem mindig alakulnak a várakozásoknak megfelelően. A hátrányos helyzetü térségekben a mikrovállalkozások számának növekedése a foglalkoztatottak arányának csökkenésével jár. Ennek magyarázata lehet a feketefoglalkoztatás és a munkaerőt egyre hatékonyabban felhasználó mezőgazdaság. Az ingázás figyelembe vételével lehetővé vált a települések munkaerőpiaci vonatkozású térségi kapcsolatainak egyszerü vizsgálata is. Megállapítottam, hogy az ingázások arányának növekedésével csökken a mikrovállalkozások számának, illetve a foglalkoztatottak arányának növekedési üteme. Sem az agglomerációs, sem a hátrányos helyzetű községekben az ingázók és a foglalkoztatottak száma között nincs kimutatható összefüggés, amit munkaerőpiaci vonatkozásban a maximális telítettségi helyzettel magyarázhatunk. Általánosságban a foglalkoztatottság bővülését az ingázás lehetősége nagymértékben magyarázza, a vizsgálat ugyanakkor azt mutatta ki, hogy az agglomerációban az ingázások eleve magas aránya, az LHH-s térségben pedig külső korlátok miatt ez a hatás kevésbé érvényesül. A modell feltárta azt is, hogy több programhatás nem a vállalkozás vagy a foglalkoztatás ösztönzésén keresztül, hanem közvetlenül járul hozzá a helyi átlagjövedelem növekedéséhez. Ez arra is utalhat, hogy a fejlesztési támogatások egy részének kedvező hatása csak a projektmegvalósítás idejéig tart, s ezáltal nem nevezhető eredményesnek. 
A kutatási eredmények érvényességét számos tényező korlátozza. Az elemzés során használt egyszerű vidékdefiníció (a vidékfejlesztési program eredményességét a községek halmazán elemeztem), illetve a kifejezetten rövid távon is érvényesülő munkaerőpiaci hatások elemzése az eredmények értelmezési tartományát szűkítik. Mindenképpen érdemes bővíteni a programok hatáselemzéseinek érvényességét más társadalmi-demográfiai magyarázó változók bevonásával, például a vándorlás és elöregedés, a népességcsökkenés, a 2012-2013-tól fokozatot váltó közfoglalkoztatás, a részletesebb ingázási mutatók, valamint a helyi gazdaságra vonatkozó további függő változók vizsgálatával. Hasonló okból a tanulmány által vizsgált komplex jelenség megértéséhez kvalitatív kutatásokat is szükséges végezni, mivel a fejlesztési hatáselemzések körében az ilyen magas érvényességü vizsgálatok jobbára hiányoznak.

\section{Jegyzetek}

1 Az agglomerációs községekben 2006 és 2016 között a bővülés mértéke közel 10\%-os, az agglomeráción kívüli községekben 14\%-os volt a teljes népességen belül. Meg kell jegyezni, hogy az adatokban a közfoglalkoztatottak is szerepelnek, akikről települési szintű adat csak 2013-tól, vagyis az EU-s költségvetési ciklus záró évétől áll rendelkezésre.

2 Az agglomerációs községekben az ingázók aránya a foglalkoztatottak körében 75\%-os, a nem agglomerációs községekben 60\%-os, ezen belül az LHH-s községekben pedig csupán 48\%-os volt a 2011-es népszámlálás szerint.

3 Ezek körében agglomerációs községeket is találunk: a közös metszet 9 település, amely az összes község 3 ezreléke.

\section{Köszönetnyilvánítás}

A tanulmány az Emberi Erőforrások Minisztériuma ÚNKP-18-3-BCE-28. kódszámú Új Nemzeti Kiválóság Programjának Támogatásával készült.

\section{Irodalom}

Adedokun, O. A., Childress, A.L., Burgess, W. D. (2011): Testing conceptual frameworks of nonexperimental program evaluation designs using structural equation modeling. American Journal of Evaluation, 4., 480-493. http://doi.org/cpk63v

Andersson, A., Höjgård, S., Rabinowicz, E. (2017): Evaluation of results and adaptation of EU rural development programmes. Land Use Policy, 67., 298-314. http://doi.org/gbn5n6

Astbury, B., Leeuw, F. L. (2010): Unpacking black boxes: Mechanisms and theory building in evaluation. American Journal of Evaluation, 3., 363-381. http://doi.org/b43dpk 
ÁSZ [Állami Számvevőszék] (2012): Jelentés a vidékfejlesztési célkitüzések megvalósitására, a helyi közösségek szerepének megerősitésére forditott pénzeszközök felhasználása eredményességének és hatékonyságának, a vidéki életminőség javitásában betöltött szerepének ellenőrzéséról. https://www.asz.hu/ storage/files/files/\%C3\%96sszes\%20jelent\%C3\%A9s/2012/1293j000.pdf (Letöltés: 2017.január 2.)

Baker, J. L. (2000): Evaluating the impact of development projects on poverty: A handbook for practitioners. World Bank Publications.

Bakucs Z., Fertő I., Benedek Zs. (2019): Success or waste of taxpayer money? Impact assessment of rural development programs in Hungary. Sustainability, 11., 2158. http://doi.org/c8wb

Bakucs Z., Fertő I., Varga Á., Benedek Zs. (2018): Impact of European Union development subsidies on Hungarian regions. European Planning Studies, 6., 1121-1136. http://doi.org/c8wc

Balás G., Csite A., Kiss G., Major K., Németh N., Piross A. (2015): Az EU-források gazdaságfejlesztési és növekedési hatásai. HÉTFA, Budapest http://hetfa.hu/wp-content/uploads/FejlpolhatasokHETFA_151130.pdf (Letöltés: 2019. január 5.)

Balogh P. (2012) Kontraproduktivitás a fejlesztéspolitikában? Az EU-források felhasználásának gazdaságszociológiai elemzése. PhD disszertáció. Budapesti Corvinus Egyetem, Szociológia Doktori Iskola, Budapest.

Barke, M., Newton, M. (1997): The EU LEADER initiative and endogenous rural development: The application of the programme in two rural areas of Andalusia, Southern Spain. Journal of Rural Studies, 3., 319-341. http://doi.org/c674jt

Bosworth, G., Annibal, I., Carroll, T., Price, L., Sellick, J., Shepherd, J. (2016): Empowering local action through neo-endogenous development; The case of LEADER in England. Sociologia Ruralis 3., 427-449. http://doi.org/c8wf

Bosworth, G., Farrell, H. (2011): Tourism entrepreneurs in Northumberland. Annals of Tourism Research, 4., 1474-1494. http://doi.org/d9bb3p

Carlsen, J., Morrison, A., Weber, P. (2008): Lifestyle oriented small tourism firms. Tourism Recreation Research, 3., 255-263. http://doi.org/c8wg

Cei, L., Defrancesco E., Stefani, G. (2018): From geographical indications to rural development: A review of the economic effects of European Union policy. Sustainability, 10., 1-21. http://doi.org/gfnd7p

Csurgó B. (2013): Vidéken lakni és vidéken élni. A városból vidékre költözók hatása a vidék átalakulására: a város környéki vidék. Argumentum, Budapest

Csurgó B., Csizmady A., Kovách I., Megyesi B. (2017): Területiség és társadalmi integráció. In: Kovách I. (szerk.): Társadalmi integráció. Az egyenlőtlenségek, az együttmúködés, az újraelosztás és a hatalom szerkezete a magyar társadalomban. MTA TK SZI, Belvedere Meridionale, Budapest, Szeged

Enyedi Gy. (2011): A városnövekedés szakaszai - újragondolva. Térés Társadalom, 1., 5-19. http://doi.org/c8wh

Esparcia Perez, J. (2000): The Leader programme and the rise of rural development in Spain. Sociologia Ruralis, 2., 200-207. http://doi.org/fsphmh

Európai Bizottság (2008): EU rural development policy. Office for Official Publications of the European Communities, Luxembourg. https://ec.europa.eu/agriculture/publi/fact/rurdev2007/2007_en.pdf (Letöltés: 2019. január 20.)

Európai Bizottság (2009): European cohesion policy in Hungary. https://ec.europa.eu/regional_ policy/sources/docgener/informat/country2009/hu_en.pdf (Letöltés: 2019. január 20.)

Fertő I., Varga Á. (2015): Az európai uniós támogatások hatása a kistérségek helyzetére. Tér és Társadalom, 1., 116-131. http://doi.org/ckhh

Juhász P. (2006): Rurális problémák: A falusi terek gazdasági, társadalmi és politikai gondjairól. In: Juhász P. (szerk.): Emberek és intézmények. Két zsákutca az agráriumban. Új Mandátum, Budapest, 573-594.

Kolosi T., Róbert P. (2004): A magyar társadalom szerkezeti átalakulásának és mobilitásának főbb folyamatai a rendszerváltás óta. TÁRKI Társadalmi Riport, 48-74.

Kovách I. (2012): A vidék az ezredfordulón. Argumentum, Budapest

Kovács Z., Egedy T., Szabó B. (2015): Az ingázás területi jellemzőinek változása Magyarországon a rendszerváltozás után Területi Statisztika, 3., 233-253. http://doi.org/c8wj

KPMG (2017): A magyarországi európai uniós források felhasználásának és hatásainak elemzése a 2007-2013-as programozási idöszak vonatkozásában. http://adko.hu/01_files/adotanulmanyok/2017/KPMG-euelemzes.pdf (Letöltve: 2019. jan. 5.) 
KSH (2014): Agglomerációk, településegyüttesek. In: Magyarország településhálózata. KSH, Budapest. http://www.ksh.hu/docs/hun/xftp/idoszaki/mo_telepuleshalozata/agglomeracio.pdf (Letöltés: 2017. január 2.)

KSH (2016): Az ingázás kiemelt célpontjai. KSH, Budapest. http://www.ksh.hu/docs/hun/xftp/ idoszaki/pdf/ingazas.pdf (Letöltve: 2019. jan. 5.)

Lakatos M., Váradi R. (2009): A foglalkoztatottak napi ingázásának jelentősége a migrációs folyamatokban. Statisztikai szemle, 7-8., 763-794.

Landi, C., Stefani G. (2015): Rent seeking and political economy of geographical indication foods. Agribusiness, 4., 543-563. http://doi.org/f7wfn8

Michalek, J., Zarnekow, N. (2012): Application of the rural development index to analysis of rural regions in Poland and Slovakia. Social Indicators Research, 1., 1-37. http://doi.org/bpxzhs

Molnár A., Hamza E., Székely E., Varga E. (2010): Az EU társfinanszírozásával megvalósuló főbb vidékfejlesztési intézkedések átfogó értékelése. In: Agrárgazdasági Információk. Agrárgazdasági Kutató Intézet, Budapest. http://repo.aki.gov.hu/310/1/ai_2010_13.pdf (Letöltés: 2019. január 5.)

Nijkamp, P., Blaas, E. (1995): Comparative regional policy impact analysis: Ex post evaluation of the performance of the European Regional Development Fund. Journal of Regional Science, 4., 579-597. http://doi.org/bmzcgr

Papadopoulou, E., Hasanagas, N., Harvey, D. (2011):Analysis of rural development policy networks in Greece: Is LEADER really different? Land Use Policy, 4., 663-673. http://doi.org/drd34b

Parasecoli, F., Tasaki, A. (2011): Shared meals and food fights: Geographical indications, rural development, and the environment. Environment and Society, 1., 106-123. http://doi.org/c8wk

Smith, N. L. (1990): Using path analysis to develop and evaluate program theory and impact. New Directions for Program Evaluation, 47., 53-57. http://doi.org/c8pz93

Szabó Zs., Balás G., Borbás G., Kiss G., Piross A., Potrovszki G., Szerletics Á. (2016): Európai uniós források rendszere 2014-2020. Gyakorlati útmutató pályázóknak és pályáztatóknak. Hétfa, KRE, ME, Budapest

Valuch T. (2015): A jelenkori magyar társadalom. Osiris, Budapest

Váradi M. M. (2015): A túlélés és a társadalmi betagozódás között: szegénység, kirekesztettség és kapcsolatrendszerek. In: Virág T. (szerk.): Törésvonalak. Szegénység és etnicitás vidéki terekben, Argumentum, Budapest, 45-68.

VÁTI (2004): Állami támogatások és programok területfejlesztési hatásainak értékelése. VÁTI, Budapest

Vidueira, P., Rivera, M., Mesa, B., Díaz-Puente, J. M. (2015): Mid-term impact estimation on evaluations of rural development programs. Procedia - Social and Behavioral Sciences, 191., 1596-1600. http://doi.org/c8wm

Vigvári A. (2015): Vissza a tanyákra - egy cigány család újrakezdési esélyei a szabolcsi pusztai világban. In: Virág T. (szerk.): Törésvonalak. Szegénység és etnicitás vidéki terekben, Argumentum, Budapest, 211-227.

Virág T. (2010): Kirekesztve. Falusi gettók az ország szélén. Akadémiai Kiadó, Budapest

VM [Vidékfejlesztési Minisztérium] (2007): Új Magyarország Vidékfejlesztési Program. Vidékfejlesztési Minisztérium, Budapest. http://www.terport.hu/webfm_send/179 (Letöltés: 2017. január 2.)

Yang, A., Rounsevell, M., Haggett, C., Piorr, A., Wilson, R. (2015): The use of spatial econometrics, stakeholder analysis and qualitative methodologies in the evaluation of rural development policy.Journal of Environmental Assessment Policy and Management, 2., 1550023. http://doi.org/c8wn 


\section{Függelék}

1. függelék: A modellekben felhasznált változók alapstatisztikái a három alcsoportban

\begin{tabular}{|c|c|c|c|c|}
\hline Mutató & Indikátor & $\begin{array}{l}\text { Agglomerációs } \\
\text { községek }\end{array}$ & $\begin{array}{c}\text { Nem agglomerációs } \\
\text { községek }\end{array}$ & LHH-s községek \\
\hline \multirow{3}{*}{$\begin{array}{l}\text { Egy főre jutó jövedelem } \\
\text { változása } 2006 \text { és } 2014 \\
\text { között (Ft, reálértéken) }\end{array}$} & Átlag & 96568 & 75437 & 93797 \\
\hline & Medián & 89123 & 73269 & 88757 \\
\hline & Szórás & 113403 & 80646 & 74519 \\
\hline \multirow{3}{*}{$\begin{array}{l}\text { Harmadik tengelyes } \\
\text { támogatások a 2007-es } \\
\text { népesség arányában }\end{array}$} & Átlag & 43036 & 61682 & 73046 \\
\hline & Medián & 28207 & 35420 & 38005 \\
\hline & Szórás & 52542 & 99007 & 122019 \\
\hline \multirow{3}{*}{$\begin{array}{l}\text { Naponta ingázó } \\
\text { foglalkoztatottak aránya } \\
(2011)\end{array}$} & Átlag & $75,3 \%$ & $60,2 \%$ & $48,7 \%$ \\
\hline & Medián & $76,2 \%$ & $62,6 \%$ & $50,0 \%$ \\
\hline & Szórás & $8,7 \%$ & $17,3 \%$ & $16,7 \%$ \\
\hline \multirow{3}{*}{$\begin{array}{l}\text { 1-9 fős regisztrált } \\
\text { vállalkozások száma (az egy } \\
\text { főre eső érték változása } \\
\text { 2006-2016 között) }\end{array}$} & Átlag & $6,51 \%$ & $9,87 \%$ & $11,55 \%$ \\
\hline & Medián & $5,73 \%$ & $8,17 \%$ & $9,84 \%$ \\
\hline & Szórás & $4,99 \%$ & $7,85 \%$ & $8,02 \%$ \\
\hline \multirow{3}{*}{$\begin{array}{l}\text { Főállású foglalkoztatottak } \\
\text { száma (az egy főre eső érték } \\
\text { változása 2006-2016 között) }\end{array}$} & Átlag & $9,88 \%$ & $14,76 \%$ & $20,12 \%$ \\
\hline & Medián & $9,58 \%$ & $13,87 \%$ & $19,61 \%$ \\
\hline & Szórás & $4,83 \%$ & $7,58 \%$ & $7,18 \%$ \\
\hline
\end{tabular}


2. függelék: A regressziós egyenesek meredekségi ( $\beta$ ) és illeszkedési (adj. $\left.R^{2}\right)$ adatai a három almintában (a két változó közötti együttmozgást akkor tüntettem fel, ha a t-próba szignifikanciája 0,05-nél alacsonyabb volt)

\begin{tabular}{|c|c|c|c|c|c|}
\hline Egyenlet & Magyarázó változó & Függő változó & $\beta$ & $\operatorname{adj} . R^{2}$ & $p$ \\
\hline \multicolumn{6}{|c|}{ Agglomeráció } \\
\hline 1 & Foglalkoztatottak & Jövedelem & 0,163 & 0,04 & $<0,000$ \\
\hline 2 & Mikrovállalkozások & Jövedelem & & & 0,372 \\
\hline 3 & Ingázók & Jövedelem & & & 0,980 \\
\hline 4 & Támogatások & Jövedelem & & & 0,746 \\
\hline 5 & Ingázók & Foglalkoztatottak & & & 0,237 \\
\hline 6 & Támogatások & Foglalkoztatottak & 0,097 & 0,007 & 0,036 \\
\hline 7 & Mikrovállalkozások & Foglalkoztatottak & 0,163 & 0,025 & $<0,000$ \\
\hline 8 & Ingázók & Mikrovállalkozások & $-0,103$ & 0,011 & 0,031 \\
\hline 9 & Támogatások & Mikrovállalkozások & 0,152 & 0,021 & 0,001 \\
\hline 10 & Támogatások & Ingázók & 0,106 & 0,009 & 0,022 \\
\hline \multicolumn{6}{|c|}{ Nem agglomeráció } \\
\hline 11 & Foglalkoztatottak & Jövedelem & & & 0,221 \\
\hline 12 & Mikrovállalkozások & Jövedelem & 0,186 & 0,034 & $<0,000$ \\
\hline 13 & Ingázók & Jövedelem & & & 0,472 \\
\hline 14 & Támogatások & Jövedelem & 0,13 & 0,017 & $<0,000$ \\
\hline 15 & Ingázók & Foglalkoztatottak & $-0,269$ & 0,072 & $<0,000$ \\
\hline 16 & Támogatások & Foglalkoztatottak & 0,099 & 0,009 & $<0,000$ \\
\hline 17 & Mikrovállalkozások & Foglalkoztatottak & & & 0,221 \\
\hline 18 & Ingázók & Mikrovállalkozások & $-0,177$ & 0,031 & $<0,000$ \\
\hline 19 & Támogatások & Mikrovállalkozások & 0,221 & 0,049 & $<0,000$ \\
\hline 20 & Támogatások & Ingázók & $-0,057$ & 0,003 & 0,006 \\
\hline \multicolumn{6}{|c|}{ LHH } \\
\hline 21 & Foglalkoztatottak & Jövedelem & 0,346 & 0,118 & $<0,000$ \\
\hline 22 & Mikrovállalkozások & Jövedelem & 0,168 & 0,027 & $<0,000$ \\
\hline 23 & Ingázók & Jövedelem & & & 0,243 \\
\hline 24 & Támogatások & Jövedelem & 0,123 & 0,014 & 0,002 \\
\hline 25 & Ingázók & Foglalkoztatottak & & & 0,074 \\
\hline 26 & Támogatások & Foglalkoztatottak & & & 0,955 \\
\hline 27 & Mikrovállalkozások & Foglalkoztatottak & $-0,174$ & 0,029 & $<0,000$ \\
\hline 28 & Ingázók & Mikrovállalkozások & $-0,155$ & 0,023 & $<0,000$ \\
\hline 29 & Támogatások & Mikrovállalkozások & 0,247 & 0,06 & $<0,000$ \\
\hline 30 & Támogatások & Ingázók & $-0,08$ & 0,005 & 0,040 \\
\hline
\end{tabular}

